\title{
Импортозамещение в отечественном сельхозмашиностроении как фактор повышения конкурентоспособности отрасли
}

\author{
Наталья Коваленко, Андрей Чекунов* \\ Российская академия народного хозяйства и государственной службы при \\ Президенте Российской Федерации, г. Ростов-на-Дону, Россия \\ Ростовский областной союз потребительских обществ, г. Ростов-на-Дону, Россия
}

Информация о статье

Поступила в редакиию.

14.02 .2019

Принята

к опубликованию: 25.09 .2019

УДК 338.22

JEL E65+ L52,62
Ключевые слова: импортозамещение, сельхозмашиностроение, субсидии, тракторы, комбайны, государственная поддержка

\section{Keywords:}

import substitution, agricultural machinery, subsidies, tractors, combines, state support

\begin{abstract}
Аннотация
Статья посвящена анализу и оченке мер государственной поддержки импортозамещения в национальном сельхозмашиностроении. Рассматриваются ход и результаты государственной поддержки импортозамещения в отрасли, недостатки, эффективность. Предложены шаги, способные повысить эффективность государственной поддержки импортозамещения в сельхозмашиностроении Российской Федераичuи.
\end{abstract}

Import Substitution in the Domestic Agricultural Machinery as a Factor in Increasing the Competitiveness of the Industry

Natalya Kovalenko, Andrey Chekunov

Abstract

Effective development of domestic agricultural engineering ensures the achievement of high production volumes of agri-food products. To improve the national production of agricultural machinery, the leading countries of the world provide state support to their producers. At the same time, these countries stimulate the development of the industry in order to dominate their producers in the domestic market, and to expand into the markets of foreign countries. For a long time, Russia has been the object of widespread expansion by foreign manufacturers of agricultural equipment. At the same time, under the conditions of economic sanctions, dependence on imported agricultural equipment limits the development of the domestic agro-industrial complex. Significantly reduce dependence on foreign supplies of agricultural equipment and ensure the competitiveness of domes- tic products should be implemented in the industry's current policy of import substitution.

* Автор для связи: chekunovandrey61@ mail.ru.

DOI: https://dx.doi.org/10.24866/2311-2271/2019-3/67-88 
The purpose of the article is to analyze the implementation of the policy of import substitution in domestic agricultural machinery and assess its impact on the development of the industry. Government support has a significant impact on the development of the industry, which is confirmed by statistical data and materials of market participants. Analysis of the literature and regulatory acts showed that the state financial support for the industry is carried out in 4 areas: industrial, technological, marketing and personnel. The effectiveness of state support is determined by the state of the industry, the situation on the domestic market of agricultural equipment and the achievement of support goals. To date, government support measures for import substitution in the industry have not ensured its stable development and increased competitiveness of the products produced. The authors analyzed the implementation of the state policy of import substitution in the domestic agricultural machinery in the framework of the relevant sectoral plan. Based on the analysis, a conclusion was made about the need to improve measures of state support for the industry.

\section{Введение}

Сельскохозяйственное машиностроение РФ является стратегически значимой подотраслью национального машиностроения, поскольку осуществляет выпуск продукции, обеспечивающей существование и развитие сельского хозяйства, а также качество и конкурентоспособность его товаров. В 2016 г. доля отечественного сельхозмашиностроения в ВВП страны составила 0,13\% [1]. Существующая на сегодняшний день ситуация на внутреннем рынке российского сельскохозяйственного машиностроения определяется двумя факторами:

- недостаточное количество сельхозтехники на площадь обрабатываемых сельхозугодий (более чем в 5 раз меньше тракторов на 1 тыс. га, чем в Канаде);

- высокая степень износа парка техники (используется 70\% машин с превышением нормативных сроков эксплуатации) [2].

Национальный рынок сельскохозяйственной техники длительное время характеризовался ростом поставок продукции зарубежных производителей. Например, в 2013 г. наблюдался рост импорта тракторов, культиваторов, плугов и косилок (на 90\%) по сравнению с предыдущим годом. Иностранные производители доминировали практически по всем видам сельскохозяйственной техники. Рост объема внутреннего рынка России полностью обеспечивался за счет увеличения импортных поставок, что привело к существенному снижению производства предприятиями сельхозмашиностроения, находящимися на территории страны. Так, по сравнению с 2012 г. их объем производства снизился на $20,7 \%$, при этом объем производства тракторов сократился на 49,9\% (импорт достиг 86,9\%), комбайновой техники на 8,6\% (зерноуборочных комбайнов на $1,3 \%$ ), а доля импорта уборочной техники в целом составила $60,9 \%$ $(+25,2 \%)$ [4]. Был также обозначен ряд проблем, препятствующих развитию отечественного сельхозмашиностроения: недостаточная конкурентоспособность, отсутствие стратегических инвесторов и прямой государственной поддержки, высокие инвестиционные риски, низкая производительность труда и высокая стоимость рабочей силы [5]. В 2014 г., несмотря на обвал национальной валюты к доллару и евро в конце года, также отмечался рост импорта некоторых видов сельскохозяйственной техники. Анализ рынка показал, что за 9 мес. 2014 г. на 36,2\% увеличился импорт тракторов мощностью 80 л.с., самоходных косилок - на 12,7\% по сравнению с аналогичным периодом прошлого года [6]. Конкурентоспособность зарубежной сельскохозяйственной техники обеспечивается за счет предложения потребителю более качественной продук- 
ции по сравнению с отечественными ее аналогами. Зарубежные производители ориентируются на новые технические решения при высоком уровне качества и соблюдении современных технологий [7].

Необходимость технологического развития отрасли и повышение конкурентоспособности продукции актуализировали вопрос об оказании поддержки данной отрасли со стороны государства. Государственная поддержка развитию национального сельскохозяйственного машиностроения оказывается в КНР, Северной Америке, Австралии и странах Европейского союза. Целью статьи является анализ государственной политики импортозамещения в отечественном сельхозмашиностроении и оценка ее влияния на развитие отрасли.

\section{Материалы и методы исследования}

Для защиты российских производителей сельхозмашиностроения применялись тарифные и нетарифные методы. В частности, в рамках Таможенного союза Евразийской экономической комиссией в феврале 2013 г. была установлена пошлина в размере $27 \%$ на ввоз зерноуборочных комбайнов и модулей к ним. Вместе с тем, в связи с отсутствием у Казахстана как крупного производителя сельхозпродукции собственного производства соответствующей сельхозтехники было принято решение с 2014 г. перейти на квотирование импорта зерноуборочных комбайнов. С 2014 по 2016 гг. был разрешен ввоз 2098 единиц техники (рис. 1).

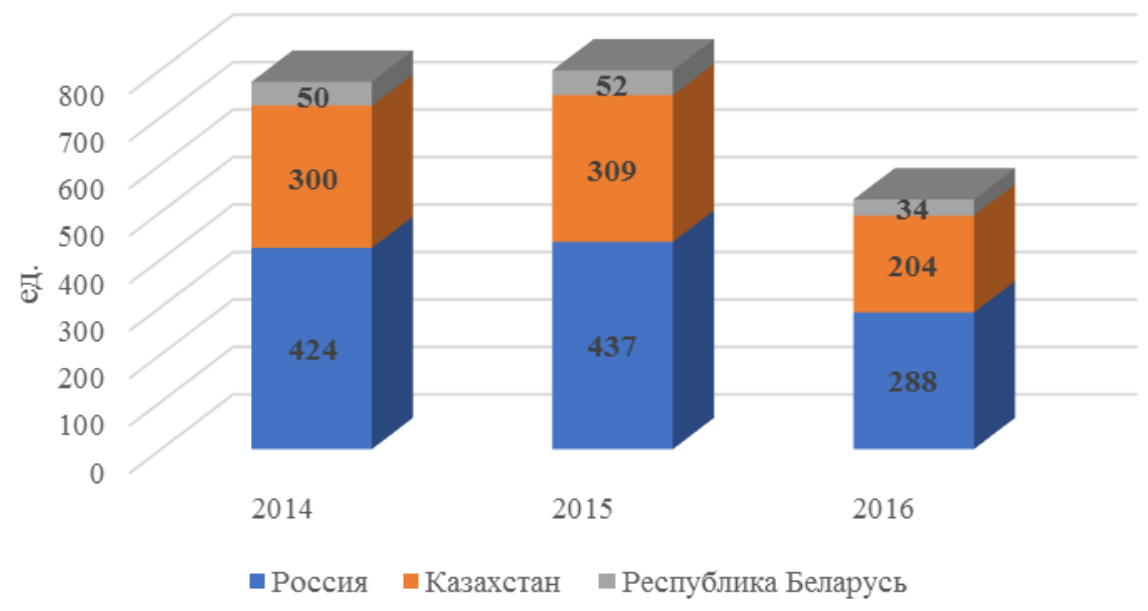

Puc. 1. Квоты на импорт зерноуборочных комбайнов для рынков соответствующих стран

Источник: составлено авторами на основе [9]

Но зарубежные производители нашли способ обходить введенные в их отношении защитные квоты. Они стали осуществлять ввоз комбайнов в разобранном виде, декларируя их как соответствующие запасные части. В январе феврале 2014 г. по такой схеме в РФ было ввезено 54 зерноуборочных комбайна на общую сумму 4,4 млн долл. США [10]. Действие импортной квоты оказало положительное влияние на развитие сельхозмашиностроения РФ. Ее применение позволило российским производителям сельскохозяйственной техники 
перейти на новый уровень и значительно улучшить конкурентные условия на внутреннем рынке. Несмотря на окончание действия импортной квоты в 2016 г., положительный эффект от ее введения будет сохраняться долгое время, поскольку она придала мощный импульс развитию отечественного сельхозмашиностроению [11]. Помимо квотирования, для поддержки национальных производителей сельхозтехники в России активно применяется механизмы субсидирования. Постановление Правительства РФ от 27.12.2012 №1432 установило правила предоставления субсидий производителям сельскохозяйственной техники. Субсидия предусматривает возмещение затрат на производство и реализацию сельскохозяйственной техники. Размер субсидии, предоставляемой производителю, составляет $15 \%$ от цены сельхозтехники без НДС и $20 \%$ в случае ее реализации сельхозтоваропроизводителям, зарегистрированных в Сибирском и Дальневосточном федеральных округах, Республике Крым, и Калининградской области. Субсидия предоставляется в целях стимулирования инвестирования в производство сельскохозяйственной техники на территории РФ. Производитель должен соответствовать следующим критериям: 1)не менее 3-х лет являться налоговым резидентом РФ и осуществлять производство сельхозтехники; 2)обладать правами на конструкторско-технологическую документацию в объеме, необходимом для осуществления разработки, производства, модернизации и обслуживания сельхозтехники, ее компонентов и оборудования; 3)предоставлять гарантию на реализуемую сельхозтехнику не менее 12 мес.; 4)обеспечивать возможность сервисного обслуживания по некоторым видам сельхозтехники не менее 1 года. Государство также предусмотрело стимулирование внедрения НИОКР производителями сельхозтехники. Постановлением Правительства РФ от 16.05.2016 №416 были утверждены правила субсидирования затрат, связанных с выпуском и поддержкой гарантийных обязательств в отношении высокопроизводительной сельхозтехники. Высокопроизводительной является техника, позволяющая снизить применение ручного труда в основных сферах экономической деятельности и увеличить производительность в них (колесные и гусеничные тракторы для сельского хозяйства, комбайны зерноуборочные, самоходные кормоуборочные комбайны, самоходная сельскохозяйственная техника прочая, прицепы для сельского хозяйства). Другим немаловажным направлением поддержки развития отрасли является обеспечение занятости в ней. Постановление Правительства РФ от 16.05.2016 №418 определило правила предоставления субсидий в целях компенсации затрат по содержанию рабочих мест. Субсидированию подлежат затраты на оплату заработной платы, исходя из среднесписочной численности работников за отчетный период, включая затраты на страховые взносы, отчисляемые в пользу работников согласно действующему законодательству РФ и возникшие с 1.01.2016 г. Субсидия выплачивается в размере $90 \%$ соответствующих затрат непосредственно производителю, либо аффилированным лицам производителей, если они оказывают услуги производителю по производству техники и (или) ее отдельных компонентов, узлов и агрегатов. Отдельным направлением поддержки отечественного сельхозмашиностроения стало субсидирование затрат на электроэнергию, понесенных предприятиями отрасли. Постановление Правительства РФ от 16.05.2016 г. №420 утвердило порядок предоставления субсидий российским производителям сельскохозяйственной техники на ком- 
пенсацию части затрат по использованию энергоресурсов энергоемкими предприятиями. Субсидия предоставляется в размере 90\% суммы затрат по электроэнергии для производства техники, возникших с 1.01.2016 г. и понесенных непосредственно производителем, либо аффилированными лицами производителей, если таковые занимаются оказанием услуг производителю по производству техники и (или) осуществлению отдельных соответствующих технологических операций, производству отдельных ее компонентов, узлов и агрегатов.

Таким образом, государственная поддержка национального сельхозмашиностроения осуществляется по следующим направлениям: производственное, технологическое, сбытовое и кадровое. Производственное, технологическое и кадровое направления поддержки отрасли впоследствии были объединены в рамках Постановления Правительства РФ от 10.02.2018 г. №145. Размер финансовой поддержки по соответствующим направлениям представлен в табл.1.

Таблица 1

Государственная поддержка сельхозмашиностроения в виде субсидий, млн. руб.

\begin{tabular}{|c|c|c|c|c|c|c|c|c|}
\hline Субсидии & 2013 & 2014 & 2015 & 2016 & 2017 & 2018 & 2019 & 2020 \\
\hline $\begin{array}{l}\text { на производство и реализацию сель- } \\
\text { скохозяйственной техники }\end{array}$ & 2300 & 1900 & 1900 & 1862 & 15700 & 10000 & 2000 & 2000 \\
\hline $\begin{array}{l}\text { на выпуск и поддержку гарантийных } \\
\text { обязательств по высокопроизводи- } \\
\text { тельной технике }\end{array}$ & - & - & - & 3961 & 6106 & \multirow[t]{3}{*}{7645} & \multirow[t]{3}{*}{7791} & \multirow[t]{3}{*}{8059} \\
\hline на содержание рабочих мест & - & - & - & 1977 & 2483 & & & \\
\hline на использование энергоресурсов & - & - & - & - & 786 & & & \\
\hline ИТОГО: & 2300 & 1900 & 1900 & 7800 & 25075 & 17645 & 9791 & 10059 \\
\hline
\end{tabular}

Источник: данные федерального бюджета, Правительства РФ и Минпромторга РФ

Как следует из данных таблицы, наибольшее финансирование отрасль получила в 2017 году. Общий объем государственной поддержки превысил соответствующее финансирование отрасли за все предшествующие годы в рамках рассматриваемого периода.

Эффективность государственной поддержки определяется состоянием отрасли, ситуации на внутреннем рынке сельскохозяйственной техники и достижением целей поддержки. В 2013 г. имело место падение объемов производства практически по всем основным видам сельскохозяйственной техники. Производство тракторов в количественном выражении по сравнению с 2012 г. снизилось на 45,5\% (из них тракторов сельхозназначения - на 49,8\%), кормоуборочных комбайнов на $44,9 \%$, плугов на $7,4 \%$, культиваторов на $29,1 \%$, косилок на $2,2 \%$, сеялок на $21,7 \%$. При этом отмечался рост производства зерноуборочных комбайнов $(1,4 \%)$ и борон (в 1,2 раза) [12]. В 2014 г. продолжилось снижение объемов производства по основным видам сельскохозяйственной техники. Производство тракторов по сравнению с 2013 г. снизилось на 20,8\%, в том числе сельскохозяйственного назначения на $16,3 \%$, зерноуборочных комбайнов на $5,9 \%$, кормоуборочных комбайнов на $18,7 \%$, плугов на $7,3 \%$, борон на $21,8 \%$, культиваторов на $21,1 \%$, косилок на $7,3 \%$. Рост наблюдался только в отношении сеялок и был незначительным (0,5\%) [13]. В 2015 г. ситуация в отечественном производстве сельскохозяйственной техники изменилась: по большинству направлений имел место рост. Так, по сравнению с 2014 г., рост про- 
изводства силосоуборочных комбайнов составил $57,5 \%$, сеялок $-13,1 \%$, косилок тракторных (без косилок-измельчителей) - 15,16\%, плугов общего назначения $-14 \%$, борон $-65,9 \%$. Снижение производства было допущено в отношении тракторов $(-23,88 \%)$, зерноуборочных комбайнов $(-17,52 \%)$ и культиваторов для сплошной обработки почв $(-8,45 \%)$ [14]. Динамика производства основных видов сельхозтехники 2013-2015 гг. указывает на нестабильное развитие отрасли. Объем государственной поддержки, предоставленный отрасли за указанный период, не обеспечил ее устойчивое развитие. Участниками отрасли подчеркивалась необходимость существенного увеличения соответствующего финансирования. В частности, по итогам состоявшегося в октябре 2014 г. Российского агротехнического форума, было предложено увеличить объем субсидирования в рамках Постановления Правительства РФ от 27.12.2012 №1432 в 2015 г. до 4000 млн руб. [15] Правительство РФ согласилось с доводами представителей отечественного сельхозмашиностроения. Распоряжением Правительства РФ от 02.04.2015 №569-р было принято решение дополнительно выделить 2000 млн руб. на предоставление соответствующих субсидий [16]. Таким образом, общий объем бюджетных средств, выделяемых на субсидирование скидки по приобретаемой сельхозтехнике в 2015 г. составил 3900 млн руб. В то же время сумма перечисленных производителям сельхозтехники бюджетных средств по итогам 2015 г. превысила данную величину и составила 5200 млн. руб. [17] В 2016 г. государство с целью обеспечения стабильного развития отрасли вводит новые формы поддержки, существенно увеличивая ее финансирование.

Первоначально запланированных в федеральном бюджете средств на субсидирование скидки производителям сельхозтехники было явно недостаточно. Потребность в финансировании по соответствующему направлению на 2016 г. составляла 15000 млн руб. [18] В связи с этим, сельхозмашиностроителями было принято решение обратиться к законодателю с просьбой об увеличении размера финансирования. Предлагалось увеличить бюджетные ассигнования на субсидирование скидки по приобретению сельхозтехники более чем в 4 раза до 8000 млн. руб. [19] Распоряжением Правительства РФ от 25.03.2016 №501-р была утверждена программа поддержки сельхозмашиностроения на 2016 г., в которой были предусмотрены дополнительно 8000 млн. руб. на соответствующую поддержку. В дальнейшем распоряжением Правительства РФ от 17.12.2016 №2699-р размер этих средств был увеличен до 9300 млн руб. Соответственно, общий объем бюджетных средств, направляемых на цели субсидирования скидки по приобретению сельхозтехники в 2016 г. составил 11160 млн руб. Бюджетная эффективность данной программы составила 187\% [20]. Вместе с тем, объем предоставленных субсидий превысил 11160 млн руб. и достиг 15000 млн руб. [21] Увеличение финансирования и появление новых форм поддержки отрасли положительным образом отразилось на ее развитии. Так, впервые за 3 года индекс производства национального сельхозмашиностроения достиг положительного значения (табл. 2). Существенный рост производства имел место в отношении всех основных видов сельскохозяйственной техники. 
Таблииа 2

Отдельные показатели деятельности сельскохозяйственного машиностроения РФ за соответствующие периоды (к предыдущему году), в \%

\begin{tabular}{|l|l|l|l|l|}
\hline Показатели/Годы & $\mathbf{2 0 1 4}$ & $\mathbf{2 0 1 5}$ & $\mathbf{2 0 1 6}$ & $\mathbf{2 0 1 7}$ \\
\hline Индекс физического объема инвестиций в основной капитал & 235 & 123,40 & 91,38 & 104,4 \\
\hline Индекс производства & 93,3 & 85,7 & 124,3 & 121 \\
\hline
\end{tabular}

Источник: составлено и рассчитано авторами по [22-26]

По сравнению с 2015 г., объем производства сельскохозяйственных тракторов вырос на $27 \%$, плугов - на $41 \%$, сеялок - на $76 \%$, косилок - на $21 \%$, зерноуборочных комбайнов - на $41 \%$ [27]. Снижение индекса физического объема инвестиций в основной капитал в 2016 г. объясняется высоким уровнем инвестиционных затрат прошлых лет, недостатком собственных средств на осуществление инвестиций, а также высокими процентными ставками по банковским кредитам. Также в 2016 г. увеличился объем производства кормоуборочных комбайнов. Их было произведено 879 шт., что на 41,7\% больше, чем в 2015 г. [28]. В 2017 г. государственная поддержка отрасли достигла максимального за 5 лет значения. Это стало результатом совместных действий представителей отечественных сельхозмашиностроителей и органов власти. Ранее представители отрасли высказывали опасения относительно возможности свертывания программы субсидирования скидок на приобретение сельхозтехники. Ее прекращение в 2017 г. они связывали с трехкратным снижением выпуска сельскохозяйственной техники национальными производителями [29]. Российские производители сельхозтехники очень зависимы от данной формы поддержки. Так, ее использование Петербургским тракторным заводом позволило более чем в 3 раза увеличить годовое производство тракторов [30]. Государство в целях оказания дальнейшей поддержки отечественным предприятиям сельхозмашиностроения по соответствующему направлению приняло решении о дополнительном выделении бюджетных средств. Распоряжением Правительства РФ от 17.04.2017 г. №715-р было выделено 13700 млн руб. на предоставление субсидий производителям сельскохозяйственной техники. Распоряжением Правительства РФ от 9.12.2017 №2747-р эта сумма была увеличена еще на 2000 млн руб. Бюджетная эффективность выделяемых средств поддержки снизилась по сравнению с 2016 г. и составила 148\% [31]. Однако данный размер финансирования не покрыл потребности отрасли. В 2017 г. они, по данным Российской ассоциации производителей специализированной техники и оборудования (Росспецмаш), составляли 18100 млн руб. [32] В то же время и выделяемый государством объем средств поддержки позволяет существенно увеличить количество закупаемой сельхозтоваропроизводителями техники. Соответствующий уровень поддержки обеспечивает приобретение более 15 тыс. ед. прицепной и навесной техники, 6 тыс. ед. зерноуборочных и кормоуборочных комбайнов, примерно 3 тыс. ед. энергонасыщенных тракторов [33]. По итогам 2017 г. число приобретенной сельхозтехники превысило этот показатель. В рамках госпрограммы субсидирования было закуплено 26,3 тыс. ед. сельхозтехники [34].

Динамика производства сельхозтехники РФ в 2017 г. не отличалась стабильностью. За 6 мес. 2017 г. наблюдался рост уровня производства по следу- 
ющим категориям: полноприводные тракторы $(+45 \%)$, плуги $(+9 \%)$, бороны $(+11 \%)$, сеялки $(+12 \%)$, зерноуборочные комбайны $(+18 \%)$, опрыскиватели $(+23 \%)$, машины для удобрения (+19\%), пресс-подборщики (+8\%) [35]. Вместе с тем, в 2017 г. имело место снижение объемов производства по многим позициям. Сокращение выпуска было зафиксировано в отношении следующих видов сельскохозяйственной техники: тракторов $(-3,7 \%)$, в том числе, тракторов сельскохозяйственного назначения $(-2,5 \%)$, промышленных тракторов $(-11,1 \%)$, кормоуборочных комбайнов $(-16,2 \%)$, культиваторов $(-37,9 \%)$, косилок $(-7,1 \%)$ [36]. При анализе результатов государственной поддержки сельхозмашиностроения за 2017 г. необходимо сопоставить прогнозные значения соответствующих показателей развития отрасли, предусмотренных Минпромторгом РФ, и их фактические значения за данный период (рис. 2). Фактическое производство отдельных видов сельхозтехники оказалось ниже запланированных Минпромторгом РФ показателей. Выпуск тракторов оказался ниже запланированного Минпромторгом РФ уровня на 258 шт. (или 9,8\%), зерноуборочных комбайнов на 544 шт. (или 8,9\%), сеялок на 488 шт. (или 4,9\%), кормоуборочных комбайнов и энергосредств на 240 шт. (или 20\%).

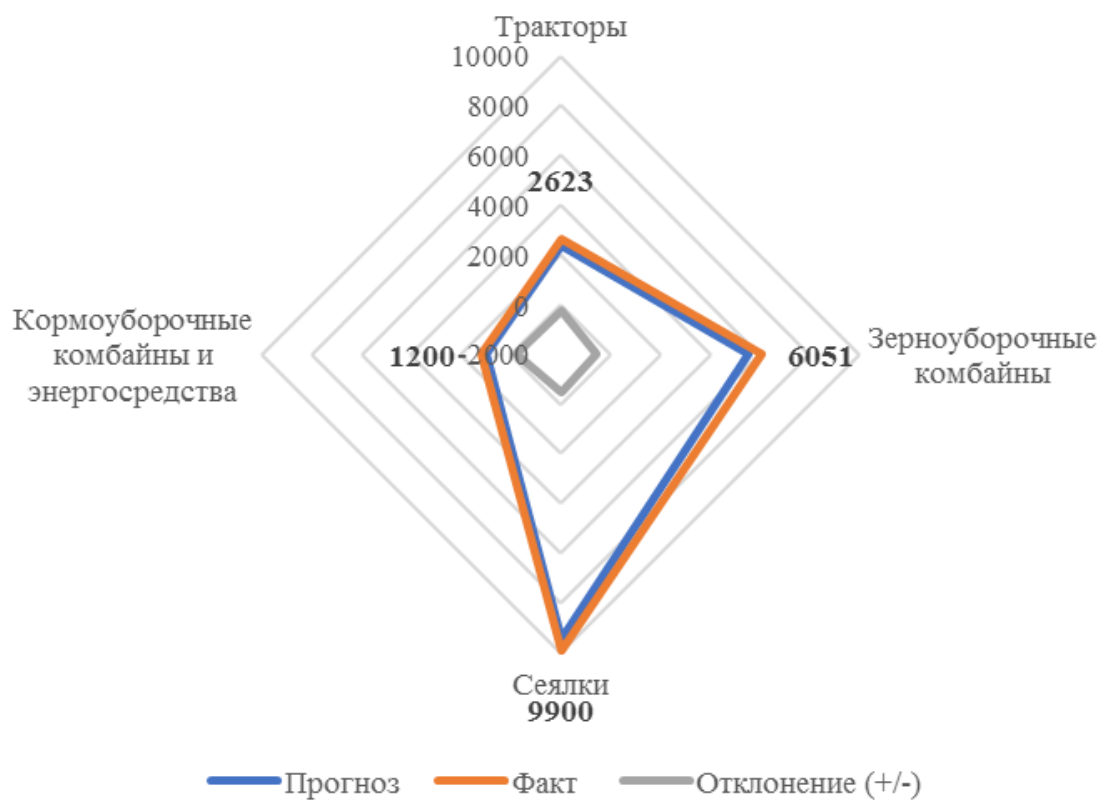

Рuc. 2. Производство отдельных видов продукции отечественными предприятиями сельхозмашиностроения в 2017 г., шт.

Источник: составлено авторами на основе [37, 38] 
Показатели общего объема производства отрасли, ее экспорта и импорта также не достигли предусмотренных Минпромторгом РФ в 2017 г. значений. Производство продукции оказалось ниже прогнозируемого уровня на 7 млрд руб., экспорта на 0,2 млрд руб. (рис. 3). Кроме того, импорт сельскохозяйственной техники превысил его прогнозное значение на 7 млрд руб. При этом необходимо отметить, что в 2017 г. имело место снижение уровня производства сельскохозяйственной техники отечественных марок по следующим позициям: тракторы $(-8,7 \%)$, кормоуборочные комбайны $(-23,85 \%)$, картофелеуборочные комбайны $(-65,5 \%)$, универсальные энергосредства $(-4,4 \%)$ [38]. Сокращение производства сельхозтехники отечественных марок в совокупности с высокой долей соответствующей техники иностранных брендов российского производства на национальном рынке и значительным увеличением импорта в 2017 г. (+42\% к 2016 г.) указывают на наличие трудностей в развитии отрасли.

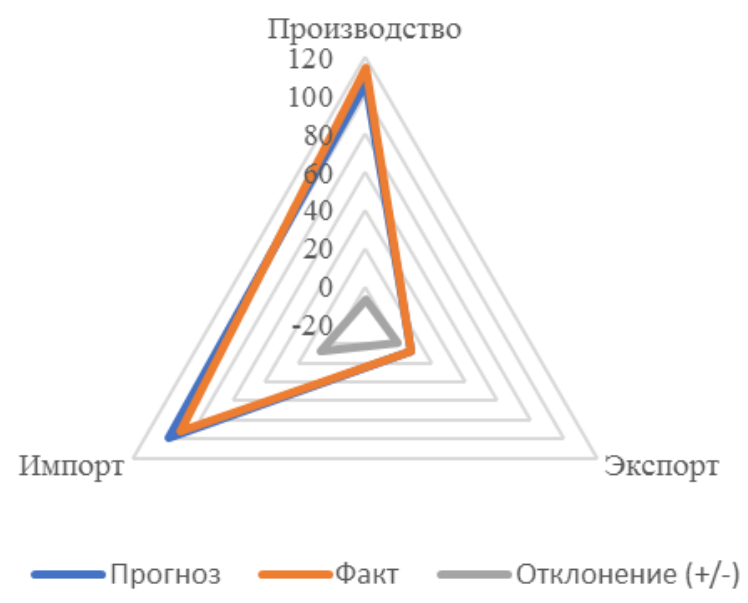

Puc. 3. Отдельные показатели сельхозмашиностроения РФ в 2017 году, млрд руб. Источник: составлено авторами на основе [37-39]

В отечественном сельхозмашиностроении за рассматриваемый период наблюдается рост численности работников и среднемесячной заработной платы (табл. 3). По сравнению с 2013 г., в 2017 г. численность работников отрасли увеличилась на 134,89\%, среднемесячная заработная плата - на 192,88\%. Рост численности работников и заработной платы последних 2-х лет в сельхозмашиностроении был обеспечен за счет предоставляемых по соответствующему направлению средств государственной поддержки. При этом если в 2017 г. рост численности работников отрасли существенно превышал средний уровень за рассматриваемый период, то рост заработной платы значительно замедлился (более чем в 2 раза ниже среднего уровня). Это объясняется снижением темпов роста производства продукции более чем в 3 раза (19,3\% против 59,6\% за период 2015-2016 гг.). Падение роста объемов производства сельхозмашиностроения и его тотальная зависимость от государственной поддержки свидетель- 
ствует о неустойчивом развитии отрасли, что препятствует эффективной реализации политики импортозамещения в ней.

Таблииа 3

Численность и оплата труда работников сельхозмашиностроения РФ за соот-

\begin{tabular}{|c|c|c|c|c|c|}
\hline Показатели/Годы & 2013 & 2014 & 2015 & 2016 & 2017 \\
\hline $\begin{array}{l}\text { Численность работников, тыс. } \\
\text { чел. }\end{array}$ & 27,8 & 27,1 & 30,8 & 33,8 & 37,5 \\
\hline $\begin{array}{l}\text { Среднемесячная заработная пла- } \\
\text { та, руб. }\end{array}$ & $\begin{array}{c}17 \\
524 \\
\end{array}$ & $\begin{array}{c}21 \\
300 \\
\end{array}$ & 27700 & $\begin{array}{c}31 \\
800 \\
\end{array}$ & $\begin{array}{c}33 \\
800 \\
\end{array}$ \\
\hline
\end{tabular}

Источник: составлено авторами на основе [31-41]

Приказом Минпромторга РФ от 31.03.2015 г. №659 был утвержден отраслевой план мероприятий по импортозамещению в сельскохозяйственном и лесном машиностроении РФ. Данным планом, в частности, предусматривается: сократить долю импорта к 2020 г. в отношении высокопроизводительного кормоуборочного комбайна до $50 \%$, лесозаготовительной техники на базе гусеничных и колесных машин до $75 \%$, тракторов сельскохозяйственного назначения различных видов до 20-80\%, высокопроизводительных зерноуборочных комбайнов до $36 \%$ [42].

Сокращение доли импортной сельхозтехники на национальном рынке имело место и до введения плана импортозамещения в отрасли, но осуществлялось крайне медленно. Так, изменение доли тракторов для сельскохозяйственных работ и лесного хозяйства отечественных марок на соответствующем рынке в 2014 г. составило только 1\% к предыдущему году [43]. При этом такой результат был достигнут на фоне общего спада производства в отрасли и роста импорта в 1 полугодии 2014 г. За 6 мес. 2014 г. по сравнению с аналогичным периодом 2013 года производство тракторов сельскохозяйственного назначения снизилось на $12,5 \%$, кормоуборочных комбайнов - на $21,9 \%$, борон - на $25,8 \%$, культиваторов - на $39,4 \%$, сеялок - на $19 \%$, косилок - на $14,9 \%$, а доля отечественных тракторов на российском рынке сократилась на $0,5 \%$ [44]. В 2015 г. темпы импортозамещения в отношении данного вида сельхозтехники несколько ускорились. По итогам 2015 г. доля соответствующих тракторов отечественных марок на внутреннем рынке увеличилась на $2,1 \%$ по сравнению с 2014 г. [45]. В этом году отмечался существенный рост экспорта отечественной продукции сельхозмашиностроения.

В 2016 г. также наблюдалось снижение импортозависимости отечественного рынка сельскохозяйственной техники. За 9 мес. 2016 г. доля зерноуборочных комбайнов отечественных марок на национальном рынке сельхозмашиностроения увеличилась с 69,6 до 72,1\% при росте их продаж на $37,2 \%$, тракторов российских брендов с 8,6 до $12,8 \%$ при росте соответствующих продаж на $13,7 \%$ по сравнению с аналогичным периодом 2015 г. [47].

\section{Результаты исследования и их обсуждение}

Принимаемые государством меры поддержки отрасли благоприятно отразились на динамике импортозамещения. Рост производства продукции сельхозмашиностроения последних лет и девальвация национальной валюты спо- 
собствовали последовательному сокращению доли импорта на соответствующем рынке. Существенное увеличение объемов финансирования государственной поддержки сельхозмашиностроения РФ и действие квоты на импорт зерноуборочных комбайнов в 2015-2016 гг. значительно ускорили замещение иностранной продукции на национальном рынке.

В 2016 году впервые удалось обеспечить доминирование отечественной продукции сельхозмашиностроения на внутреннем рынке, сократив долю зарубежной продукции на 15\% по сравнению с 2015 годом (рис. 4). Доля отечественных производителей на национальном рынке сельхозмашиностроения в 2016 году составила 55\%, увеличившись по сравнению с 2013 годом более чем в 2 раза. Д. Медведев, отмечая положительный эффект импортозамещения в отрасли, заявил, что доля сельскохозяйственной техники отечественного производства в 2016 году на российских полях превысила 50\% [51]. В то же время в 2017 г. темпы импортозамещения в отрасли значительно снизились.

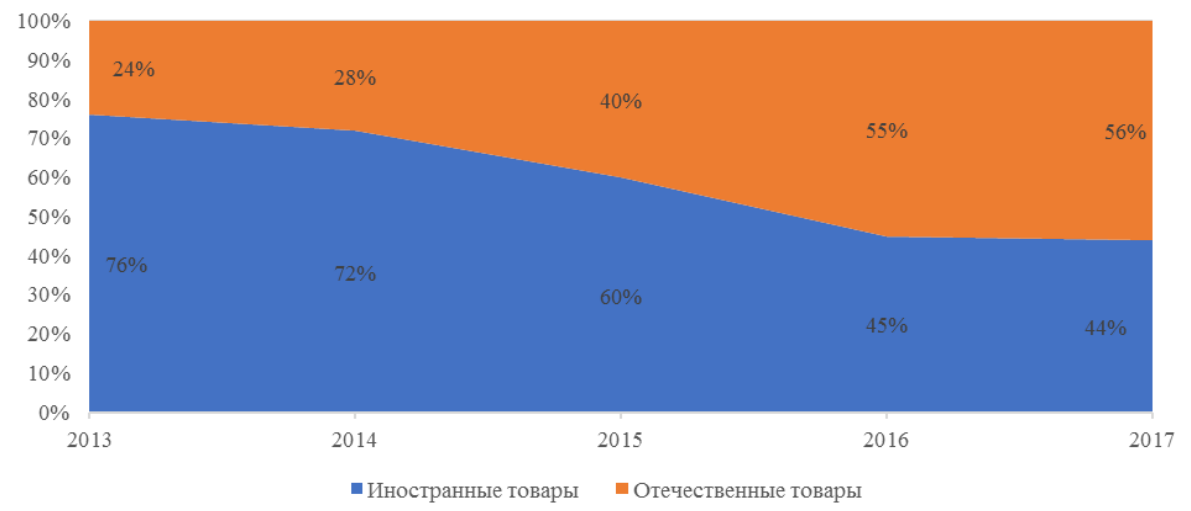

Puc. 4. Доля сельхозтехники отечественного производства на национальном рынке, \% Источник: составлено авторами на основе [48-50]

Существенный рост импорта наблюдался по большинству основных товарных направлений отрасли. Например, за первые 3 мес. 2017 г. по сравнению с аналогичным периодом прошлого года импорт сельскохозяйственных тракторов мощностью более 80 л.с. вырос почти в 2,5 раза, зерноуборочных комбайнов в 7 раз, самоходных косилок в 20 раз, самоходных опрыскивателей на $51,3 \%$, зарубежные поставки кормоуборочных комбайнов в данный период составили $50 \%$ от уровня 2016 г. [52]. Замедление импортозамещения в сельхозмашиностроении связывается с возможностью получения иностранными производителями государственной поддержки, неравными условиями конкуренции с зарубежными производителями и укреплением рубля. Низкие ставки по кредитам, невысокая по сравнению с РФ стоимость электроэнергии, возможность получения поддержки от двух источников (национальных и российских властей) обеспечивают зарубежному производителю преимущество в продвижении собственной продукции на отечественный рынок сельхозмашиностроения. При этом укрепление рубля удешевляет продукцию зарубежных конкурентов на 20-40\%, повышая ее привлекательность, и, соответственно, снижает весь эффект от господдержки [53]. 
Зарубежные производители сельскохозяйственной техники предпринимают большие усилия, чтобы получить статус «российского производителя сельхозтехники» в целях получения финансовой поддержки со стороны государства. Немецкая компания «Клаас» обеспечила в 2017 г. приемлемый уровень локализации производства сельхозтехники в России, позволяющий ей претендовать на государственные субсидии. Это позволило заключить специальный инвестиционный контракт, закрепляющий соответствующий статус компании и предоставляющей ей возможность реализации 400 ед. сельхозтехники стоимостью более 4 млрд руб. Известный производитель сельскохозяйственной техники CNH Industrial (торговые марки NewHolland и Case) также заинтересован в получении статуса «российского производителя сельхозтехники». Для этого планируется повышение уровня локализации производства на территории России посредством увеличения прямых инвестиций [54]. Существовавшие в 2017 г. тенденции на национальном рынке сельскохозяйственной техники негативно отразились на импортозамещении в отрасли. Иностранные производители начали вытеснять производителей отечественных марок сельхозтехники даже с тех позиций, в которых они традиционно удерживали лидерство, чего не наблюдалось в течение 3-х лет (2014-2016 гг.). В 2017 г. производители отечественных марок сократили свое присутствие на рынке зерноуборочных комбайнов на $5,1 \%$, кормоуборочных комбайнов на $12,35 \%$ по сравнению с 2016 г. (рис. 5). Увеличение доли иностранных зерноуборочных комбайнов на отечественном рынке сельхозмашиностроения обусловлено отменой соответствующей квоты. Рост присутствия кормоуборочных комбайнов иностранного производства на рынке объясняется невозможностью восполнить соответствующей продукцией российского производства его потребности (спад производства в 2017 г.).

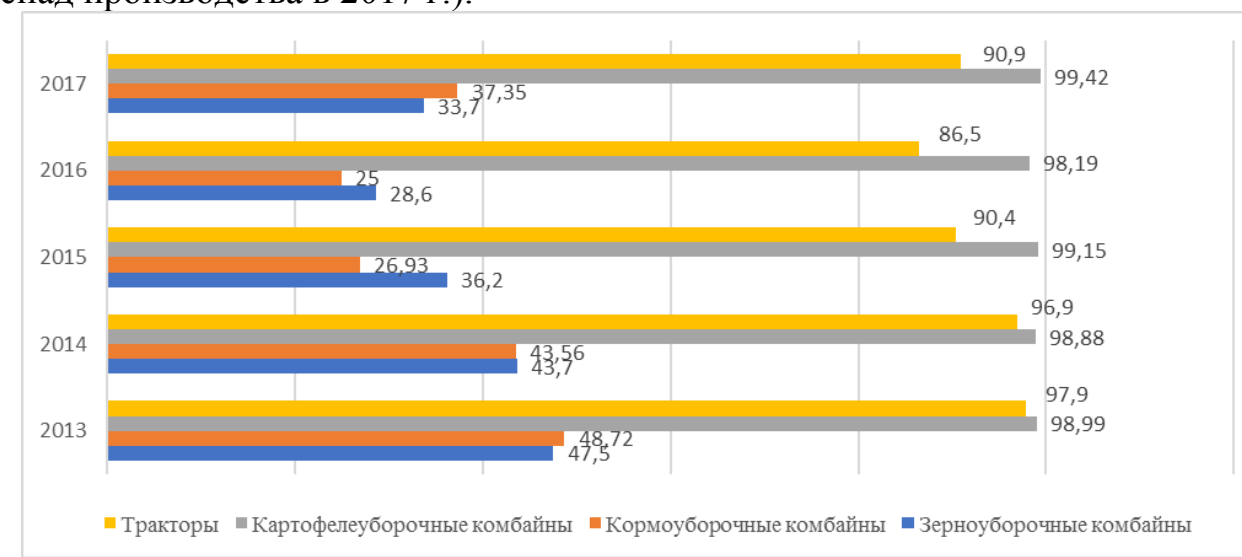

Puc. 5. Доля некоторых видов иностранной сельхозтехники на российском рынке за соответствующие периоды, \%

Источник: составлено авторами на основе [38, 55-58]

В отношении лесозаготовительной техники существующие темпы импортозамещения не способствуют достижению $25 \%$ доли отечественных производителей на соответствующем рынке к 2020 году. Предпринимаемые государством меры пока не способы существенным образом изменить ситуацию на рынке лесозаготовительной техники. Собственное производство лесозаготови- 
тельной техники практически отсутствует и на его восстановление в объеме, необходимом для удовлетворения потребностей отечественных лесозаготовителей, требуются существенные ресурсы. В то же время перспективы совместной сборки лесозаготовительных машин известных брендов российскими и иностранными компаниями оцениваются пессимистично [59].

Государство стремится развивать собственное производство соответствующей техники. В 2016 г. Онежскому тракторному заводу Минпромторгом РФ был одобрен займ в размере 107 млн. руб. для осуществления инвестпроекта по разработке и производству импортозамещающих гусеничных и колесных комплексов лесозаготовительной техники. В рамках данного проекта планируется изготовление отечественных харвестеров, форвардеров (база колесного шасси $6 x 6$ и $8 \mathrm{x} 8$ ) и скиддеров (колесная база $4 \mathrm{x} 4$ ) [60]. Вместе с тем, результаты проводимого государством импортозамещения в отношении лесозаготовительной техники пока несущественны (табл. 4). Очевидно, что для стабилизации положения на российском рынке лесозаготовительной техники потребуется значительное время. Импортозамещение в отношении тракторов для сельскохозяйственных работ и лесного хозяйства и картофелеуборочных комбайнов также практически не осуществляется. Зарубежные производители по данным видам сельскохозяйственной техники

прочно удерживают свои позиции на отечественном рынке. Так, из общего объема проданных тракторов на национальном рынке за январь - декабрь 2016 года, который составил 20,8 тыс. ед., только 2854 ед. тракторов отечественных марок [62]. За рассматриваемый период сложилась определенная структура импортных поставок сельскохозяйственных тракторов. Большая часть ввозимых в РФ тракторов производится в Белоруссии, около 9\% китайского производства, 8\% приходится на японских производителей [63].

Таблийа 4

Доля зарубежной продукции

\begin{tabular}{|} 
на национальном рынке лесозаготовительной техники, \% \\
\hline & $\mathbf{2 0 1 5}$ & $\mathbf{2 0 1 6}$ & $\mathbf{2 0 1 7}$ \\
\hline Харвестеры & 97,15 & 99,6 & 99,78 \\
\hline Форвардеры & 90,03 & 39,02 & 94,64 \\
\hline Скиддеры & 100 & 100 & н/д \\
\hline
\end{tabular}

Источник: составлено авторами на основе [61]

Основная причина доминирования сельскохозяйственных тракторов зарубежного производства на национальном рынке сельхозмашиностроения заключается в большем разнообразии модельного ряда и их технических характеристик. Представленные на отечественном рынке модели сельскохозяйственных тракторов российского производства не в полной мере учитывают почвенно-климатические условия хозяйств, их размеры и специализацию, что способствует быстрой адаптации зарубежных производителей к потребностям рынка [64]. Наибольшая зависимость российского рынка от импорта зарубежной сельскохозяйственной техники в настоящее время имеет место по картофелеуборочным комбайнам. При этом в 2017 году был достигнут наивысший показатель импортозависимости по данному виду сельхозтехники. Необходимость 
создания новых моделей российских картофелеуборочных комбайнов обусловлена ростом сектора картофелеводства в 3 раза, что предусматривает увеличение спроса на современную технику [65]. Картофелеуборочные комбайны отечественного производства имеют потенциал для развития. У них есть одно неоспоримое и доказанное преимущество перед аналогичной зарубежной техникой. Отечественные картофельные комбайны имеют меньшую по сравнению с ними материалоемкость, что положительно отражается на плодородии почв [66]. К этому следует добавить более низкую в сравнении с зарубежными производителями соответствующей продукции стоимость комбайна, меньшие габариты и массу механизма, доступность сервиса и запчастей, а также пригодность к климатическим условиям.

Государственная поддержка пока не обеспечила решение проблемы модернизации сельского хозяйства. В структуре основных видов сельскохозяйственной техники существенную долю занимают машины старше 10 лет. Например, по данным за 2016 год среди парка тракторов они составляли 59,7\%, зерноуборочных комбайнов $45,6 \%$, кормоуборочных комбайнов 44,6\% [67]. В сельском хозяйстве РФ имеет место тенденция сокращения парка сельскохозяйственной техники. Так, в 2014-2016 гг. парк тракторов сократился на 17294 ед., зерноуборочных комбайнов на 4077 ед., кормоуборочных комбайнов на 2670 ед. [68]. Данные обстоятельства свидетельствуют о необходимости совершенствования государственной поддержки развития отечественного сельхозмашиностроения. Существующие условия позволяют ее получать зарубежным производителям сельскохозяйственной техники, что дестимулирует развитие отечественного производства. В конечном итоге, ценовое преимущество сельхозтехники отечественного производства фактически нивелируется, что приводит к снижению ее востребованности на соответствующем рынке, а, следовательно, создание новых рабочих и внедрение новых технологий становится нецелесообразным [69]. Через механизм локализации зарубежные производители сельхозтехники добиваются наиболее благоприятных условий на внутрироссийском рынке. Об этом, в частности, свидетельствуют сокращение объема производства отечественных марок сельхозтехники и их доли на национальном рынке. Кроме того, возникают споры о фактическом уровне локализации производства для целей получения государственной поддержки. Если иностранные производители оценивают локализацию собственного производства на территории РФ в 50-60\%, то производители отечественных марок указывают лишь на диапазон 10-35\% [70]. В дополнении к этому, указывается, что субсидирование скидок на приобретение сельхозтехники приводит к монополизации соответствующего рынка и препятствует технологической модернизации отрасли. Субсидия снижает производительность труда, т.к. ее объем зависит от численности работников, а в субсидируемой технике используются узлы и агрегаты зарубежных производителей, 70\% соответствующей поддержки получает «Ростсельмаш» и его дочерние структуры [71]. Возникают также сложности с оценкой эффективности мер государственной поддержки. В соответствии с правилами предоставления субсидий, утвержденных постановлениями Правительства РФ от 16.05.2016 №№416, 418 и 420, оценка Минпромторгом РФ эффективности использования соответствующих средств осуществляется исходя из показателей, утверждённых самими получателями государственной под- 
держки. Одновременно с этим, в качестве оценочных показателей, характеризующих влияние господдержки на развитие предприятия, не предусмотрены соответствующими нормативно-правовыми актами, такие как: рентабельность, коэффициент текущей ликвидности, производительность труда, трудоёмкость, средний срок эксплуатации оборудования, процент загрузки мощностей [72].

\section{Выводы}

Существующая система государственной поддержки сельхозмашиностроения пока не обеспечивает в полной мере выполнение показателей по импортозамещению, предусмотренных отраслевым планом. Об этом свидетельствует рост импортных поставок зарубежной техники на внутренний рынок. Соответственно, необходима корректировка мер государственной поддержки сельхозмашиностроения. Она должна обеспечить устойчивое развитие отрасли и выполнения плана импортозамещения в ней. Для выполнения этих задач необходимо: 1)предоставлять государственную поддержку только производителям сельхозтехники отечественных марок; 2)активно использовать нетарифные меры для защиты внутреннего рынка; 3)контролировать ценообразование у получателей государственной поддержки; 4)не допускать использование в субсидируемой технике узлов и агрегатов иностранного производства, за исключением тех, производство которых не налажено в РФ; 5)в целях мониторинга эффективности господдержки установить в числе необходимых показателей такие, как производительность труда, доля инновационной продукции в общем объеме отгруженных товаров, уровень загруженности производственных мощностей, коэффициент обновления основных средств, рентабельность затрат, коэффициент финансовой устойчивости и рентабельность производства.

\section{Список источников / References}

1. Место сельхозмашиностроения в экономике РФ. [Mesto sel'hozmashinostroeniya v ekonomike RF [The place of agricultural engineering in the economy of the Russian Federation]]. Available at: https://www.kommersant.ru/doc/3260406 (accessed 13.06.2018).

2. Российское сельхозмашиностроение: «стратегическое» развитие, экспорт и производство комплектующих. [Rossijskoe sel'hozmashinostroenie: «strategicheskoe» razvitie, eksport i proizvodstvo komplektuyushchih [Russian agricultural machinery:

«strategic» development, export and production of components]]. Available at: http://svetich.info/publikacii/agrohimija/rossiiskoe-selhozmashinostroenie-strateg.html (accessed 13.06.2018).

3. Россия жестко ограничила импорт сельхозтехники. [Rossiya zhestko ogranichila import sel'hoztekhniki [Russia severely restricted imports of agricultural equipment]]. Available at: http://agropages.ru/page/9556.shtml (accessed 14.06.2018).

4. Российский рынок сельхозтехники в 2013 году. Кто чего и сколько продал. [Rossijskij rynok sel'hoztekhniki v 2013 godu. Kto chego i skol'ko prodal[Russian agricultural machinery market in 2013. Who sold what and how much]]. Available at: http://agroobzor.ru/?dn=sht\&id=226\&to=art(accessed 14.06.2018).

5. Рынок сельхозтехники в 2013 году. [Rossijskij rynok sel'hoztekhniki v 2013 godu [Russian agricultural machinery marketin 2013]]. Available at: https://www.agroxxi.ru/selhoztehnika/yeksklyuziv/rynok-selhoztehniki-v-2013godu.html(accessed 14.06.2018). 
6. Импорт сельхозтехники в Россию в 2014 году. [Import sel'hoztekhniki v Rossiyu v 2014 godu [Import of agricultural machinery to Russia in 2014]]. Available at: https://www.agroxxi.ru/selhoztehnika/stati/import-selhoztehniki-v-rossiyu-v-2014godu.html (accessed 14.06.2018).

7. Лаврова Н.А. Состояние и проблемы функционирования рынка уборочных машин в РФ и Амурской области. Дальневосточный аграрный вестник, 2013,№3 (27), сc.30-

33. [Lavrova N.A. Sostoyanie i problemy funkcionirovaniya rynka uborochnyh mashin v RF i Amurskoj oblasti[State and problems of functioning of the market of cleaning ma- chines in the Russian Federation and the Amur region]. Dal'nevostochnyj agrarnyj vestnik= Far Eastern Agrarian Bulletin, 2013, no. 3(27), pp.30-33.

8. Точный выбор. Требуются изменения в структуре производства сельхозтехники. [Tochnyj vybor. Trebuyutsya izmeneniya v strukture proizvodstva sel'hoztekhniki [Exact selection. Changes in the structure of agricultural machinery production are required]]. Available at: https://rg.ru/2014/10/14/selhoztehnika.html (accessed 14.06.2018).

9. На комбайнах в бадминтон. [Na kombajnah v badminton [On combines in badminton]]. Available at: http://expert.ru/ural/2014/10/na-kombajnah-v-badminton/(accessed 15.06.2018).

10. Комбайны разобрались в импорте. [Kombajny razobralis' v importe [Combines understand import]]. Available at: https://www.autostat.ru/articles/16294/ (accessed 15.06.2018).

11. Тульцева А. С. Импортная квота на зерноуборочные комбайны как специальная защитная мера. Маркетинг и логистика, 2017, №2 (10), cc. 107-119. [Tul'ceva A. S. Importnaya kvota na zernouborochnye kombajny kak special'naya zashchitnaya mera [Import quota for combine harvesters as a special protective measure]. Marketing i logistika= Marketing and logistics, 2017, no. 2 (10), pp. 107-119.

12. Тракторное и сельскохозяйственное машиностроение России в 2013 году. [Traktornoe i sel'skohozyajstvennoe mashinostroenie Rossii v 2013 godu [Tractor and agricultural engineering of Russia in 2013]]. Available at: http://soyuzagromash.info/news/id173(accessed 19.06.2018).

13. Тракторное и сельскохозяйственное машиностроение России в 2014 году (по данным компании «АСМ-холдинг»). [Traktornoe i sel'skohozyajstvennoe mashinostroenie Rossii v 2014 godu (po dannym kompanii «ASM-holding») [Tractor and agricultural machine-building of Russia in 2014 (according to the company «ASM-holding»)]]. Available at: http://soyuzagromash.info/news/id233(accessed 19.06.2018).

14. Обзор состояния отрасли сельскохозяйственного машиностроения России и Краснодарского края 2017. [Obzor sostoyaniya otrasli sel'skohozyajstvennogo mashi- nostroeniya Rossii i Krasnodarskogo kraya 2017 [Review of the state of the agricultural engineering industry in Russia and Krasnodar Krai 2017]]. Available at: http://dppkk.ru/upload/iblock/0f4/0f43b3c896de32de27676a3f13f6daec.pdf.

15. Национальный исследовательский университет Высшая школа экономики. Центр развития. Рыноксельскохозяйственных машин 2016 год. [Nacional'nyj issledovatel'skij universitet Vysshaya shkola ekonomiki. Centr razvitiya. Rynok sel'skohozyajstvennyh mashin 2016 god [National Research University Higher School of Economics. Development Center. Agricultural machinery market 2016]]. Available at: https://dcenter.hse.ru/data/2016/12/29/1114670197/Рынок\%20сельскохозяйственных\% 20машин\%202016.pdf.

16. Жамбалнимбуев Б.-Ж. Отчет о результатах контрольного мероприятия «Проверка эффективности реализации первоочередных мероприятий по стимулированию спроса на отечественную сельскохозяйственную технику в 2015 году». Бюллетень Счетной палаты Российской Федерации, 2015, №8(212), cc. 3-49. [ZHambalnimbuev B.-ZH. Otchet o rezul'tatah kontrol'nogo meropriyatiya «Proverka effektivnosti realizacii 
pervoocherednyh meropriyatij po stimulirovaniyu sprosa na otechestvennuyu sel'skohozyajstvennuyu tekhniku v 2015 godu» [Report on the results of the control measures

«Verifying the effectiveness of the implementation of priority measures to stimulate de- mand for domestic agricultural machinery in 2015»]. Byulleten' Schetnoj palaty Ros- sijskoj Federacii $=$ Bulletin of the Accounts Chamber of the Russian Federation,2015, no. 8(212), pp. 3-49.

17. Продолжается реализация программы субсидирования в рамках Постановления Правительства Российской Федерации №1432. [Prodolzhaetsya realizaciya programmy subsidirovaniya v ramkah Postanovleniya Pravitel'stva Rossijskoj Federacii №1432 [The implementation of the subsidy program is continuing under the Government Decree No. 1432]]. Available at: http://www.agrotrak.ru/news/1-latest-news/216--1432 (accessed 20.06.2018).

18. Росагромаш. Производство сельскохозяйственной техники в России: тенденции и потенциал. Москва, 2016. [Rosagromash. Proizvodstvo sel'skohozyajstvennoj tekhniki v Rossii: tendencii i potencial. Moskva, 2016 [Rosagromash. Agricultural machinery production in Russia: trends and potential. Moscow 2016]]. Available at: http://atf.rosspetsmash.ru/upload/iblock/cc9/babkin_2016.pdf.

19. Владимир Гутенев считает необходимым увеличение финансирования программы производителей сельскохозяйственной техники до 8 млрд. рублей в 2016 году. [Vladimir Gutenev schitaet neobhodimym uvelichenie finansirovaniya programmy proizvoditelej sel'skohozyajstvennoj tekhniki do 8 mlrd. rublej v 2016 godu[Vladimir Gu- tenev considers it necessary to increase funding for the program of manufacturers of agricultural machinery to 8 billion rubles in 2016]]. Available at: http://swissrus.ru/news/partner-news/vladimir-gutenev-schitaet-neobhodimym-uvelichenie- finansirovaniya-programmy-subsidirovaniya-proizvoditeley-sel-skohozyaystvennoy- tehniki-do8-mlrd-rubley-v-2016-godu.html?curPos=40(accessed 20.06.2018).

20. Союз машиностроителей России. Росспецмаш. Состояние и перспективы развития производства специализированной техники в Российской Федерации. Москва, 2017. [Soyuz mashinostroitelej Rossii. Rosspecmash. Sostoyanie i perspektivy razvitiya proizvodstva specializirovannoj tekhniki v Rossijskoj Federacii. Moskva, 2017[Russian Engineering Union. Rosspetsmash. The state and prospects of development of the production of specialized equipment in the Russian Federation. Moscow, 2017]]. Available at: http://www.rosspetsmash.ru/attachments/article/1810/ Презентация\%20Ассоциация\%20Росспецмаш.pdf.

21. Внесены изменения в программу субсидирования производителей сельхозтехники. [Vneseny izmeneniya v programmu subsidirovaniya proizvoditelej sel'hoztekhniki [Changes have been made to the program of subsidizing agricultural machinery manufacturers]]. Available at: http://www.rosagromash.ru/32-uncategorised/1046-vneseny- izmeneniya-v-programmu-subsidirovaniya-proizvoditelej-selkhoztekhniki(accessed 20.06.2018).

22. Национальный исследовательский университет Высшая школа экономики. Центр развития. Рыноксельскохозяйственных машин 2017 год. [Nacional'nyj issledovatel'skij universitet Vysshaya shkola ekonomiki. Centr razvitiya. Rynok sel'skohozyajstvennyh mashin 2017 god [National Research University Higher School of Economics. Development Center. Agricultural machinery market 2017 year]]. Available at: https://dcenter.hse.ru/data/2018/02/03/1163430452/Рынок\%20сельскохозяйственных\% 20машин\%202017.pdf.

23. Производство российской сельхозтехники в 2017 году выросло на 21\%. [Proizvodstvo rossijskoj sel'hoztekhniki v 2017 godu vyroslo na 21\% [The production of Russian agricultural machinery in 2017 increased by 21\%]].Available

at: http://rosagromash.ru/novosti-otrasli/2233-proizvodstvo-rossijskojselkhoztekhniki-v- 2017-godu-vyroslo-na-21(accessed 13.06.2018). 
24. Почукаев К.Г. Инвестиционный фактор и ценовая конкурентоспособность сельскохозяйственной и железнодорожной техники. Научные труды. Москва, Ин-т народнохозяйственного прогнозирования PAH, 2017. 568 c. [Pochukaev K.G. Investicionnyj faktor i cenovaya konkurentosposobnost' sel'skohozyajstvennoj i zheleznodorozhnoj tekhniki [Investment factor and price competitiveness of agricultural and railway equipment]. Nauchnye Trudy [Scientific works]. Moscow, Institute of Economic Forecasting, Russian Academy of Sciences, 2017. 568 p.

25. Худжатов М. Б. Применение таможенных инструментов стимулирования иностранных инвестиций в сельскохозяйственное машиностроение России. Маркетинг и логистика, 2018, №1 (15), cс. 58-70. [Hudzhatov M. B. Primenenie tamozhennyh instrumentov stimulirovaniya inostrannyh investicij $\mathrm{v}$ sel'skohozyajstvennoe mashi- nostroenie Rossii [The use of customs instruments to stimulate foreign investment in agricultural engineering of Russia]. Marketing i logistika= Marketing and logistics, 2018, no. 1 (15), pp. 58-70.

26. Обзор: результат 2017 года в машиностроении - лучший за пять лет. [Obzor: rezul'tat 2017 goda v mashinostroenii - luchshij za pyat' let [Review: the result of 2017 in mechanical engineering is the best in five years]]. Available at: http://www.riarating.ru/comments/20180322/630086387.html(accessed 13.06.2018).

27. Обзор рынка отдельных видов сельскохозяйственной техники. 2016 год. [Obzor rynka otdel'nyh vidov sel'skohozyajstvennoj tekhniki. 2016 god [Market review of certain types of agricultural equipment. 2016 year]]. Available at: https://www.vvs- info.ru/helpful_information/poleznaya-informatsiya/obzor-rynka-otdelnykh-vidovselskokhozyaystvennoy-tehniki/(accessed 20.06.2018).

28.ЕЭК. Анализ производства (локализации) сельскохозяйственной техники в Евразийском экономическом союзе по видам производства, Москва - 2017 г. [ЕЕК. Analiz proizvodstva (lokalizacii) sel'skohozyajstvennoj tekhniki v Evrazijskom ekonomicheskom soyuze po vidam proizvodstva, Moskva - $2017 \mathrm{~g}$ [ECE. Analysis of the production (localization) of agricultural machinery in the Eurasian Economic Union by type of production, Moscow - 2017]]. Available at: http://www.eurasiancommission.org/ru/act/prom_i_agroprom/dep_agroprom/monitoring/ Documents/Анализ\%20локализации\%20сельхозтехники\%20в\%20EAЭС.pdf.

29. В 2017 году выпуск сельхозтехники может упасть втрое. [V 2017 godu vypusk sel'hoztekhniki mozhet upast' vtroe [In 2017, the output of agricultural machinery can fall threefold]]. Available at: http://ati.su/Media/News.aspx?HeadingID=8\&ID=109159(accessed 21.06.2018).

30. В 2017 году субсидирование выпуска сельхозтехники будет урезано. [V 2017 godu subsidirovanie vypuska sel'hoztekhniki budet urezano [In 2017, subsidies for the production of agricultural equipment will be curtailed]]. Available

at: http://www.tsenovik.ru/news/Novosti-APK/Tekhnika-i-oborudovanie/V-2017godusubsidirovanie-vypuska-selkhoztekhniki-budeturezano/?sphrase_id=1376839(accessed 21.06.2018).

31. Росспецмаш. Состояние и перспективы развития отечественного сельхозмашиностроения. Благовещенск, 2018. [Rosspecmash. Sostoyanie i perspektivy razvitiya otechestvennogo sel'hozmashinostroeniya. Blagoveshchensk, 2018 [Rosspetsmash. The state and prospects of development of domestic agricultural machinery. Blagoveshchensk, 2018]]. Available at:

http://www.agroamur.ru/news/2018/2018/201803281/2018-03$21 \% 20$ Астахова\%20А.В.Состояние\%20и\%20перспективы\%20развития\%20отечеств енного\% 20 сельхозмашиностроения.pdf.

32. Росспецмаш. Состояние и перспективы развития производства сельхозтехники в Российской Федерации. Москва, 2017. [Rosspecmash. Sostoyanie i perspektivy 
razvitiya proizvodstva sel'hoztekhniki v Rossijskoj Federacii. Moskva, 2017 [Rosspetsmash. The state and prospects for the development of agricultural machinery production in the Russian Federation. Moscow, 2017]]. Available at: http://komitet220.km.duma.gov.ru/upload/site2/document_news/000/526/513/Babkin.ppt.

33. В 2017 году российские аграрии закупят более 22 тысяч единиц сельхозтехники. [V 2017 godu rossijskie agrarii zakupyat bolee 22 tysyach edinic sel'hoztekhniki [n 2017, Russian farmers will purchase more than 22 thousand units of agricultural equipment]]. Available at: http://kvedomosti.ru/news/v-2017-godu-rossijskie-agrarii-zakupyat-bolee22-tysyach-edinic-selxoztexniki.html(accessed 21.06.2018).

34. Импортозамещение в сельском хозяйстве идет ударными темпами - Ростислав Гольдштейн. [Importozameshchenie v sel'skom hozyajstve idet udarnymi tempami Rostislav Gol'dshtejn [Import substitution in agriculture is accelerating - Rostislav Goldstein]]. Available at: https://sakhalinmedia.ru/news/666870/(accessed 28.06.2018).

35. Данные Агропродмаш. [Dannye Agroprodmash [Data Agroprodmash]]. Available at: http://www.agroprodmash-expo.ru/ru/ui/17121/(accessed 21.06.2018).

36. СФНЦА РАН: СТАТИСТИКА.СЕЛЬХОЗТЕХНИКА. [SFNСА RAN: STATISTIKA.SEL'HOZTEKHNIKA [SFNTSA RAS: STATISTICS. SELKHOZTEKHNIKA]]. Available at:

http://www.sorashn.ru/index.php?id=2257\&tx_ttnews[pointer]=15\&tx_ttnews[tt_news]=3 865\&tx_ttnews[backPid] $=1362 \&$ cHash $=7813639$ b1dce8db693d3b7af39820b55(accessed 21.06.2018).

37. Минпромторг России. Текущее состояние и перспективы развития сельскохозяйственного машиностроения январь-август 2017 г. [Minpromtorg Rossii. Tekushchee sostoyanie i perspektivy razvitiya sel'skohozyajstvennogo mashinostroeniya yanvar'avgust 2017 g [The Ministry of Industry and Trade of Russia. The current state and prospects for the development of agricultural engineering January-August 2017]]. Available at: http://kemdep.ru/images/doc/Deytelnoct/Gospod/Sel-hoz_machine.pdf.

38. Национальный аграрный каталог «Сельхозтехника». Аналитика - итоги 2017 года. [Nacional'nyj agrarnyj katalog «Sel'hoztekhnika». Analitika - itogi 2017 goda [National agricultural catalog «Agricultural». Analytics - the results of 2017]]. Available at: http://www.selhoz-katalog.ru/pdf/kat_selhoz_17-2018.pdf (accessed 31.05.2018).

39. Производство российской сельхозтехники в 2017 году выросло на 21\%.[Proizvodstvo rossijskoj sel'hoztekhniki v 2017 godu vyroslo na 21\% [The production of Russian agricultural machinery in 2017 increased by $21 \%]]$. Available at: https://gisp.gov.ru/news/8630042/ (accessed 21.06.2018).

40. Рыкова И.Н., Метелькова Е.О. Эффективность мер государственной поддержки в области сельскохозяйственного машиностроения. Финансовый журнал, 2016, №3, cc.98-104. [Rykova I.N., Metel'kova E.O. Effektivnost' mer gosudarstvennoj podderzhki v oblasti sel'skohozyajstvennogo mashinostroeniya [Effectiveness of state support measures in the field of agricultural engineering]. Finansovyj zhurnal= Financial journal,2016, no. 3,pp. 98-104.

41. Росспецмаш. Современная сельскохозяйственная техника России. Калининград, 2017. [Rosspecmash. Sovremennaya sel'skohozyajstvennaya tekhnika Rossii. Kaliningrad, 2017 [Rosspetsmash. Modern agricultural equipment of Russia. Kaliningrad, 2017]]. Available at: http://mcx39.ru/wp-content/uploads/2017/06/1Maksimkin-novyj.ppt.

42. Available at: https://gisp.gov.ru/plan-import-change/6451129/\#popdoc(accessed 25.06.2018).

43. Российский рынок тракторов для сельскохозяйственных работ и лесного хозяйства в 2014 году. [Rossijskij rynok traktorov dlya sel'skohozyajstvennyh rabot i lesnogo hozyajstva v 2014 godu[The Russian market of tractors for agricultural work and forestry in 2014]]. Available at: http://soyuzagromash.info/news/id235(accessed 25.06.2018). 
44. Тракторное и сельскохозяйственное машиностроение России за январь-июнь 2014 года. [Traktornoe i sel'skohozyajstvennoe mashinostroenie Rossii za yanvar'-iyun' 2014 goda [Tractor and agricultural machinery of Russia for January-June 2014]]. Available at: http://www.soyuzagromash.info/news/id212 (accessed 25.06.2018).

45. Российский рынок тракторов для сельскохозяйственных работ и лесного хозяйства в январе-декабре 2015 года. [Rossijskij rynok traktorov dlya sel'skohozyajstvennyh rabot i lesnogo hozyajstva v yanvare-dekabre 2015 goda [The Russian market of tractors for agricultural work and forestry in January-December 2015]].Available at: http://soyuzagromash.info/news/id297(accessed 25.06.2018).

46. Роагромаш. Развитие сельхозпроизводства и сельскохозяйственного машиностроения Российской Федерации. Москва, 2015. [Roagromash. Razvitie sel'hozproizvodstva i sel'skohozyajstvennogo mashinostroeniya Rossijskoj Federacii [Roagromash. Development of agricultural production and agricultural engineering of the Russian Federation. Moscow, 2015. Moskva, 2015]]. Available at: http://atf.rosspetsmash.ru/upload/present2015/babkin.pdf.

47. Рынок зерноуборочных комбайнов и тракторов в России за первые 3 квартала 2016 года. [Rynok zernouborochnyh kombajnov i traktorov v Rossii za pervye 3 kvartala 2016 goda [The market of combine harvesters and tractors in Russia for the first 3 quarters of 2016]]. Available at: http://comtrans.biz/news/industry/rynok-zernouborochnykhkombaynov-i-traktorov-v-rossii-za-pervye-3-kvartala-2016-goda-289933/ (accessed 25.06.2018)

48. Страна уставших тракторов. Почему в России сельхозтехника работает на износ. [Strana ustavshih traktorov. Pochemu v Rossii sel'hoztekhnika rabotaet na iznos [Country of tired tractors. Why in Russia agricultural machinery is working for wear]]. Available at: http://www.forbes.ru/biznes/pmef-2018362081-strana-ustavshih-traktorov-pochemuv-rossii-selhoztehnika-rabotaet-na-iznos(accessed 03.06.2018).

49. Русская доля. Отечественные производители в 2016 году заняли 55\% российского рынка сельхозтехники. [Russkaya dolya. Otechestvennye proizvoditeli v 2016 godu zanyali 55\% rossijskogo rynka sel'hoztekhniki [Russian share. In 2016, domestic producers accounted for $55 \%$ of the Russian agricultural machinery market]]. Available at: http://vestnikapk.ru/articles/importozameshchenie/russkaya-dolya/ (accessed 03.06.2018).

50. В 2017 году выпуск сельхозтехники может упасть втрое. [V 2017 godu vypusk sel'hoztekhniki mozhet upast' vtroe [In 2017, the output of agricultural equipment may fall threefold]]. Available at: http://ati.su/Media/News.aspx?HeadingID=8\&ID=109159(accessed 03.06.2018).

51. В 2016 году доля российской сельхозтехники на полях России составила более 50\%

- председатель Правительства. [V 2016 godu dolya rossijskoj sel'hoztekhniki na polyah Rossii sostavila bolee 50\% - predsedatel' Pravitel'stva [In 2016, the share of Russian agricultural equipment in the fields of Russia was more than $50 \%$ - the Prime Minister]]. Available at: https://www.pnp.ru/economics/2017/04/19/v-2016-godu-dolyarossiyskoy- selkhoztekhniki-na-polyakh-rossii-sostavila-bolee-50-predsedatel- pravitelstva.html(accessed 26.06.2018).

52. Импорт в Россию с/х техники по итогам 2016 года. [Import v Rossiyu s/h tekhniki po itogam 2016 goda [Import to Russia of agricultural machinery by the end of 2016]]. Available at:

http://vch.ru/event/view.html?alias=import_v_rossiyu_sh_tehniki_po_itogam_2016_goda( accessed 27.06.2018).

53. «Мы не за создание тепличных условий, а за выравнивание условий» - производители агромашин о положении на рынке. [«My ne za sozdanie teplichnyh uslovij, a za vyravnivanie uslovij» - proizvoditeli agromashin o polozhenii na rynke [«We are not for the creation of greenhouse conditions, but for leveling the conditions» - manufacturers of agricultural machines on the marketsituation]]. Available at: 
https://news.rambler.ru/other/39373354-my-ne-za-sozdanie-teplichnyh-usloviy-a-zavyravnivanie-usloviy-proizvoditeli-agromashin-o-polozhenii-na-rynke/?updated(accessed 27.06.2018).

54. Алексеев К.И. Импортозамещение на рынке сельскохозяйственной техники России. Вестник сельского развития и социальной политики, 2017, №4(16), сc. 31-36. [Alekseev K.I. Importozameshchenie na rynke sel'skohozyajstvennoj tekhniki Rossii [Import substitution on the Russian agricultural machinery market]. Vestnik sel'skogo razvitiya i social'noj politiki=Bulletin of rural development and social policy, 2017, no. 4 (16), pp.31-36.

55. Российский рынок зерноуборочных комбайнов в России в январе-декабре 2016 года. [Rossijskij rynok zernouborochnyh kombajnov v Rossii v yanvare-dekabre 2016 goda [The Russian market of combine harvesters in Russia in January-December 2016]]. Available at: http://soyuzagromash.info/news/id338(accessed 31.05.2018).

56. Российский рынок зерноуборочных комбайнов в России в январе-декабре 2015 года. [Rossijskij rynok zernouborochnyh kombajnov v Rossii v yanvare-dekabre 2015 goda [Russian market of combine harvesters in Russia in January-December 2015]]. Available at: http://soyuzagromash.info/news/id296(accessed 31.05.2018).

57. Российский рынок сельхозтехники в 2014 году. [Rossijskij rynok sel'hoztekhniki v 2014 godu [Russian agricultural machinery market in 2014]]. Available at: https://agroinfo.com/rossijskij-rynok-selxoztexniki-v-2014-godu-1603201505/(accessed 01.06.2018).

58. Российский рынок сельхозтехники в 2016 году. [Rossijskij rynok sel'hoztekhniki v 2016 godu [Russian agricultural machinery market in 2016]]. Available at: https://agroinfo.com/2303201704-rossijskij-rynok-selxoztexniki-v-2016-godu/(accessed 01.06.2018).

59. Быть или не быть... русскому харвестеру? [Byt' ili ne byt'... russkomu harvesteru? [Тo be or not to be ... a Russian harvester?]]. Available at: http://www.lesprominform.ru/jarchive/articles/itemshow/4003(accessed 29.06.2018).

60. Онежскому тракторному заводу одобрен займ на разработку и производство колесных и гусеничных комплексов лесозаготовительной техники. [Onezhskomu traktornomu zavodu odobren zajm na razrabotku i proizvodstvo kolesnyh i gusenichnyh kompleksov lesozagotovitel'noj tekhniki [Onego tractor plant approved a loan for the development and production of wheeled and tracked complexes of logging equipment]]. Available at: http://www.wood.ru/ru/lonewsid-67112.html (accessed 29.06.2018).

61. Таможенная статистика внешней торговли РФ. [Tamozhennaya statistika vneshnej torgovli RF [Customs statistics of foreign trade of the Russian Federation]]. Available at: http://stat.customs.ru/analytics/saw.dll?Answers\&SubjectArea="Доступ\%20TCВT"(acce ssed 29.06.2018).

62. Российский рынок тракторов в январе - декабре 2016 года. [Rossijskij rynok traktorov v yanvare - dekabre 2016 goda [The Russian tractor market in January - December 2016]]. Available at: http://soyuzagromash.info/news/id337(accessed 28.06.2018).

63. Импорт сельскохозяйственной техники в Россию снизился на 12\%. [Import sel'skohozyajstvennoj tekhniki v Rossiyu snizilsya na 12\% [Import of agricultural machinery to Russia decreased by $12 \%]$ ]. Available at: https://marketing.rbc.ru/articles/9887/(accessed 28.06.2018).

64. Подшивалова В.В. Механизм повышения эффективности таможенного регулирования импорта сельскохозяйственной техники в Российскую Федерацию. Дисс. канд. экон. наук. Люберцы, 2018. 217 с. [Podshivalova V.V. Mekhanizm povysheniya effektivnosti tamozhennogo regulirovaniya importa sel'skohozyajstvennoj tekhniki $\mathrm{v}$ Rossijskuyu Federaciyu. Diss. kand. ekon. nauk [The mechanism of improving the effi- 
ciency of customs regulation of imports of agricultural machinery in the Russian Federation. Cand. diss. (Econ)]. Lyubertsy, 2018. 217 p.]

65. Рынок сельхозтехники в России: мнение мировых экспертов. [Rynok sel'hoztekhniki v Rossii: mnenie mirovyh ekspertov [Agricultural machinery market in Russia: the opinion of world experts]]. Available at: https://www.agroxxi.ru/selhoztehnika/stati/rynokselhoztehniki-v-rossii-mnenija-mirovyh-yekspertov.html(accessed 29.06.2018).

66.7 причин, почему следует отказаться от приобретения импортного картофелеуборочного комбайна. [7 prichin, pochemu sleduet otkazat'sya ot priobreteniya importnogo kartofeleuborochnogo kombajna [7 reasons why you should abandon the acquisition of imported potato harvester]]. Available at: http://selhoztehnika.net/news-777/7-prichinpochemu-sleduet-otkazatsya-ot-priobreteniya-importnogo-kartofeleuborochnogo- kombajna(accessed 29.06.2018).

67. Polukhin A.A. Evaluation of the technological development of agriculture: the technical aspect. Russian Journal of Agricultural and Socio-Economic Sciences, 2017, no. 6(66), pp. 23-36.

68. Годовой отчет ОАО «САРЭКС» за 2016 год. [Godovoj otchet OAO «SAREKS» za $2016 \operatorname{god}[$ Annual report of OJSC «SAREX» for 2016]]. Available at: https://disclosure.1prime.ru/Portal/GetDocument.aspx?emId=1325009287\&docId=9b766c 84ea3a4250b60688cb69ada41f.

69. Иностранные производители сельхозтехники получили федеральные преференции. [Inostrannye proizvoditeli sel'hoztekhniki poluchili federal'nye preferencii Foreign manu- facturers of agricultural equipment received federal preferences]]. Available at: http://foconsult.ru/smi/i480-inostrannye-proizvoditeli-selhoztehniki-poluchili- federalnye.html(accessed 2.07.2018).

70. Скандальная господдержка импорта. [Skandal'naya gospodderzhka importa [Scandal- ous state support for imports]]. Available at: http://expert.ru/south/2016/06/skandalnaya- $\quad$ gospodderzhka-importa/(accessed 2.07.2018).

71. «Ъ»: агропром хочет забрать субсидии у машиностроителей. [«"»: agroprom hochet zabrat' subsidii u mashinostroitelej [«Kommersant»: the agroprom wants to take subsidies from machine builders]]. Available at: https://milknews.ru/index/APKselhoztehnik- gospodderzhka.html(accessed 3.07.2018).

\section{Сведения об авторах / About authors}

Коваленко Наталья Валерьевна, доктор экономических наук, профессор, профессор кафедры менеджмента Южно-российского института управления Российской академии народного хозяйства и государственной службы при Президенте Российской Федерации (РАНХиГС). 344002 Россия, Ростов-на-Дону, улица Пушкинская, 70/54. E-mail: sonatak96@gmail.com

Natalya V. Kovalenko, Doctor of Economics Sciences, Professor, Professor of the Department «Man- agement» of South-Russian Institute of Management of the Russian Academy of National Economy and Public Administration under the President of the Russian Federation (RANEPA). 344002, Russia, Ros- tov-on-Don, street Pushkinskaya, 70/54. E-mail: sonatak96@gmail.com

Чекунов Андрей Сергеевич, кандидат экономических наук, главный специалист-эксперт по развитию кооперации Ростовского областного союза потребительских обществ. 344002 Россия, Ростов-на-Дону, проспект Буденновский, 19a/55. E-mail: chekunovandrey61@ mail.ru

Andrey S. Chekunov, Candidate of Economics, Chief Expert on Development of Cooperation of Rostov Regional Union of Consumer Societies. 344002, Russia, Rostov-on-Don, Budennovsky Ave, 19a /55. E- mail: chekunovandrey61@mail.ru 